\title{
Ethnobotanical and Plant Profile Studies at Karimunjawa Village of Jepara Regency, Central Java
}

\author{
Tutik Nurhidayati ${ }^{1}$, Dian Saptarini ${ }^{1}$, Nurul Jadid ${ }^{1}$, dan Listiani
}

\begin{abstract}
Ethnobotanical and plant profile studies that had been conducted at Karimunajawa Village of Jepara Regency were aimed to elucidate plants used by the Karimunjawa villagers and typical plants of the Karimunjawa as well as their usage. The method used for this study was questionnaire, structured and semistructured interviews. Conditions of Karimunjawa typical plants in their natural habitats were measured through bell transects that were determined based on questionnaire previously filled by the villagers. Results of the study showed that there were 39 species of wild and cultivated plants used by villagers. The plants were used for building materials $(39.77 \%)$, food $(23.86 \%)$, handicraft and souvenir $(23.29 \%)$, furniture $(5.11 \%)$, ship construction $(3.40 \%)$, medicine $(2.84 \%)$, and fuel wood $(\mathbf{1 . 7 0 \%})$. There were three species of typical plants found in the Karimunjawa Islands, i.e. Dewadaru (Fragraea elliptica), Setigi (Pemphis acidula), and Kalimasada (Cordia subcordata). Profile of the typical plants indicated that at the Karimunjawa Village there were sixty four individual Dewadaru and two Setigi in their narural habitats. However, no Kalimasada was found in its original habitat; the Kalimasada found in this area was that of previously planted.
\end{abstract}

Keywords - Ethnobotany, Karimunjawa, Fragraea elliptica, Pemphis acidula, Cordia subcordata

\section{Pendahuluan}

$\mathbf{I}_{\mathrm{k}}^{\mathrm{n}}$ ndonesia dikenal sebagai negara megabiodiversiti karena memiliki kekayaan sumber daya alam yang sangat banyak. Beberapa daerah memiliki beragam jenis tumbuhan etnik yang mencirikan eksistensi suku bangsa di daerah tersebut. Tumbuhan etnik umumnya tidak dibudidayakan tetapi dibiarkan tumbuh alami. Kelompok masyarakat memanfaatkan tumbuhan etnik untuk mendukung kebutuhan sehari-hari [1].

Kapasitas pemanfaatan dan pengelolaan keragaman hayati sangat bervariasi dan dipengaruhi oleh faktor budaya, nilai sosial, perbedaan lokasi, implementasi pembangunan wilayah dan akses terhadap informasi dan teknologi. Komponen-komponen keanekaragaman hayati selama ini telah dimanfaatkan untuk berbagai kebutuhan manusia, namun pemanfaatan yang tidak bijaksana akan menyebabkan kerusakan habitat dan

Naskah diterima pada tanggal 18 Desember 2008, Selesai revisi pada 3 Februari 2009

Tutik Nurhidayati, Dian Saptarini, dan Nurul Jadid adalah dosen Jurusan Biologi, FMIPA, Institut Teknologi Sepuluh Nopember, Surabaya, INDONESIA.

E-mail: tutik@bio.its.ac.id, dian@bio.its.ac.id, nuruljadid@bio.its.ac.id punahnya spesies serta terjadinya erosi keragaman genetik [1].

Upaya konservasi keanekaragaman hayati pada dasarnya sudah diwujudkan oleh pemerintah Indonesia dengan membuat kelompok-kelompok Taman Nasional di berbagai daerah di Indonesia. Salah satunya adalah Taman Nasional Karimunjawa yang berada di Kepulauan Karimunjawa [1].

Kepulauan Karimunjawa terdiri 27 gugusan pulau yang memiliki tipe ekosistem hutan hujan dataran rendah, padang lamun, algae, hutan pantai, hutan mangrove dan terumbu karang. Dua puluh tujuh gugusan pulau tersebut, hanya lima pulau yang berpenghuni, yaitu pulau karimunjawa, pulau Kemujan, pulau Parang, pulau Nyamuk, dan pulau Genting. Dua puluh dua pulau lainnya sudah masuk dalam zonasi balai Taman Nasional Karimunjawa [2].

Masyarakat di Kepulauan Karimunjawa sangat majemuk dan multienis. Antara lain Jawa, Madura, Bugis (Sulawesi selatan) dan Bajau (Sulawesi Utara). Kemajemukan masyarakat tersebut memiliki potensi yang berbeda-beda dalam hal pemanfaatan, cara pengolahan, dan keragaman tumbuhan etniknya. Verdasarkan obvervasi yang pernah dilakukan tingkat pendidikan penduduk di kepulauan Karimunjawa rata-rata masih rendah dan sebagian besar masyarakatnya bekerja sebagai nelayan dan pengrajin kayu. Sebagai pengrajin kayu, yang dilakukan oleh masyarakat setempat adalah memanfaatkan kayu yang tumbuh secara liar di lingkungan sekitar termasuk kawasan Taman Nasional. Rendahnya tingkat pendidikan masyarakat menyebabkan minimnya pemahaman terhadap pentingnya taman Nasional sebagai penyangga ekologi. Hal ini dapat diamati dengan masih berlangsungnya ekspoitasi kayu-kayu dari hutan untuk keperluan kerajinan kayu, sehingga perlu adanya pelestarian tumbuhan-tumbuhan yang berpotensi untuk meningkatkan perekonomian masyarakat setempat [1].

Tumbuhan-tumbuhan yang menjadi ciri khas di Kepulauan Karimunjawa dan berpotensi meningkatkan perekonomian masyarakat setempat antara lain Dewadaru (Fragraea elliptica) yang terdapat pada hutan hujan dataran rendah, Setigi (Pemphis acidula) serta Kalimasada (Cordia subcordata) yang terdapat di hutan pantai [1]. Pemanfaatan tumbuhan tersebut oleh masyarakat Desa Karimunjawa dapat mengancam eksistensinya apabila tidak disertai dengan perbaruan. Untuk dapat mengetahui kondisi perbaruan suatu tumbuhan dapat dilihat dari komposisi stratifikasinya, yaitu antara pohon, tiang, pancang, dan semai mem- 
punyai komposisi yang seimbang sehingga eksistensi tumbuhan dapat tetap terjaga [3].

Penelitian mengenai studi pemanfaatan tumbuhan bernilai etnik dan komersial di Kepulauan Karimunjawa ini merupakan suatu kajian startegis untuk mendapatkan data atau informasi eksistensi tumbuhan etnik dan pemanfaatannya oleh masyarakat Desa Karimunjawa. Data ini lebih lanjut dapat digunakan sebagai acuan dalam rangka pelestarian plasma nutfah tumbuhan etnik dan bernilai komersial tinggi oleh pemerintah daerah setempat dan dinas yang terkait. Halhal yang melatar belakangi pemilihan lokasi tersebut antara lain : kawasan Karimunjawa dihuni oleh beberapa etnis yang berbeda; lokasi kepulauan yang cukup jauh dari pusat kabupaten dan aktivitas pemanfaatan tumbuhan etnik yang cukup tinggi.

Tingkat keanekaragaman tumbuhan terestrial yang dimiliki oleh kepulauan Karimunjawa sangat tinggi karena di kepulauan Karimunjawa terdapat empat macam vegetasi yaitu hutan hujan dataran rendah, hutan pantai, hutan mangrove, dan terumbu karang dan padang lamun. Penelitian etnobotani hanya dilakukan terhadap tumbuhan yang dimanfaatkan oleh masyarakat Desa Karimunjawa sedangkan profil tumbuhan ha- nya dibuat untuk tumbuhan yang dianggap menjadi ciri khas kepulauan Karimunjawa dan dimanfaatkan oleh masyarakat Desa Karimunjawa.

Penelitian ini bertujuan untuk mengetahui jenis tumbuhan yang dimanfaatkan penduduk Desa Karimunjawa dalam kehidupan sehari-hari dan profil tumbuhan yang dijadikan sebagai ciri khas kepulauan Karimunjawa oleh penduduk Desa Karimunjawa beserta nilai etnobotaninya.

Manfaat yang diperoleh dari penelitian ini adalah diperoleh data jenis tumbuhan yang dimanfaatkan masyarakat Desa Karimunjawa dalam kehidupan seharihari dan diketahui profil tumbuhan khas kepulauan Karimunjawa beserta nilai etnobotaninya.

\section{Metode Penelitian}

Penelitian dilakukan di Desa Karimunjawa, kecamatan Karimunjawa, kabupaten Jepara, Jawa Tengah selama 1 bulan pada bulan Mei-Juni 2007.
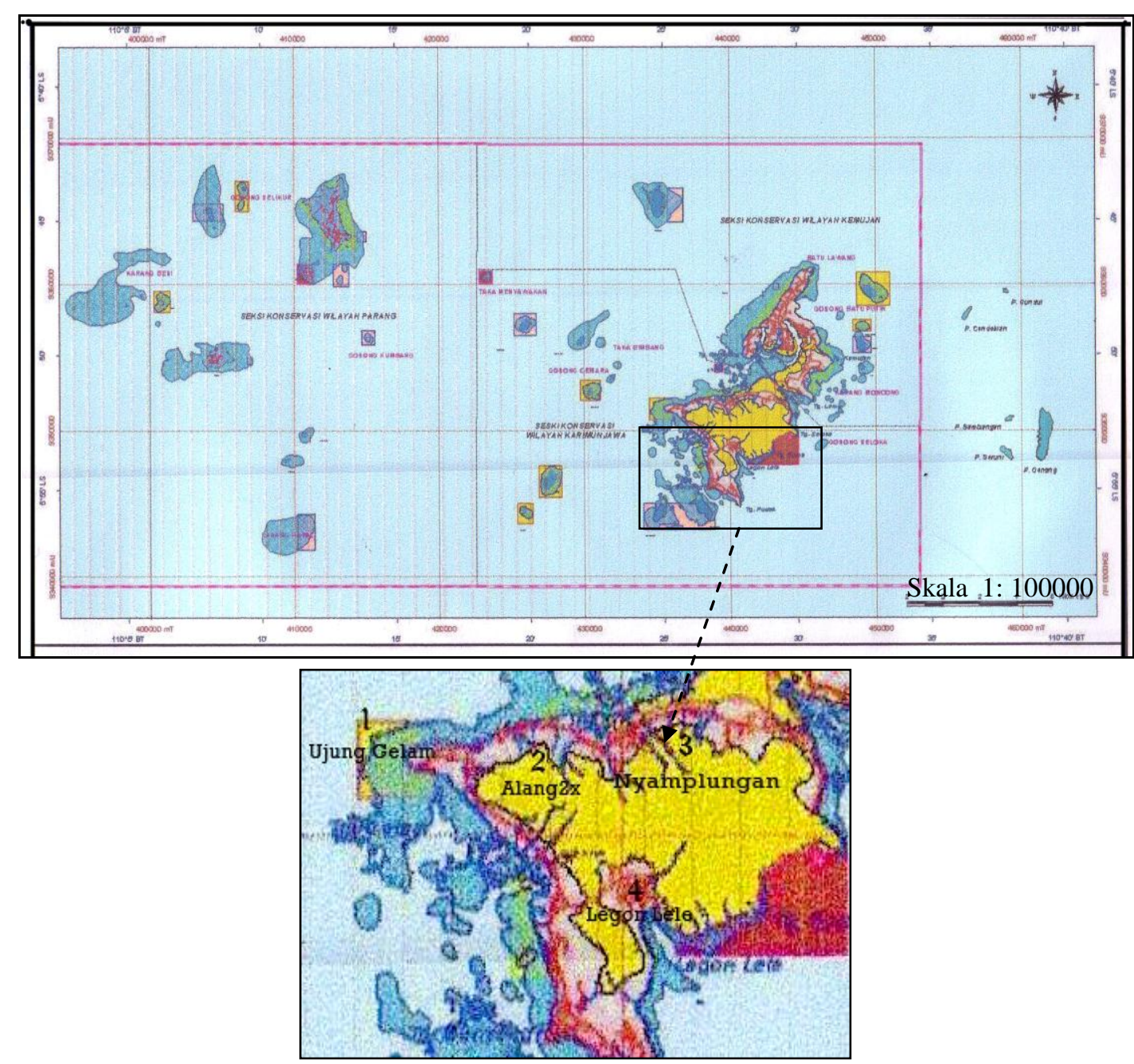

Gambar 1. Lokasi Penelitian

(Sumber : Taman Nasional Karimunjawa [11]) 
Selain wawancara terstruktur, juga dilakukan wawancara semi-struktur terhadap beberapa informan kunci seperti ketua adat atau dukun adat. Perhitungan jumlah total sampel (responden) dilakukan dengan menggunakan formula Lynch dkk.[5] dalam Iskandar [6]:

$\mathrm{n}_{\mathrm{T}}=\frac{\mathrm{N}_{\mathrm{T}} Z^{2} \cdot \mathrm{P}(1-\mathrm{P})}{\mathrm{N}_{\mathrm{T}} \mathrm{d}^{2}+\mathrm{Z}^{2} \cdot \mathrm{P}(1-\mathrm{P})}$

Keterangan:

$$
\begin{array}{lll}
\mathrm{n}_{\mathrm{T}} & : & \text { Jumlah Total sampel (responden) } \\
\mathrm{N}_{\mathrm{T}} & : & \text { Jumlah Total Populasi } \\
\mathrm{Z} & : & \text { Nilai variabel Normal (1.96) } \\
\mathrm{P} & : & \text { Proporsi Kemungkinan terbesar (0.50) } \\
\mathrm{d} & : & \text { Sesatan sampling }(0.10)
\end{array}
$$

Pengumpulan Data di Lapangan. Setelah diperoleh data jenis tumbuhan khas kepulauan Karimunjawa kemudian dilanjutkan dengan mengamati kondisi tumbuhan di lapangan. Pengumpulan data dilakukan dengan menggunakan metode belt, yaitu hanya dengan mengamati obyek yang dimaksud (tumbuhan khas kepulauan Karimunjawa yang bernilai etnik dan komersial) kemudian diambil data kelimpahan (abundance) pohon berdasarkan ukuran kelas tumbuhan (pohon, tiang, sapihan, dan semai). Metode belt dilakukan dengan membuat 3 transek dengan lebar 10 meter dan panjang disesuaikan dengan kondisi lapangan. Jarak antar transek sekitar 500 meter [7]. Data hasil pengamatan di lapangan kemudian disajikan dalam bentuk tabel dan grafik.

Analisis Data. Data-data yang diperoleh dari hasil kuisioner kemudian disajikan dalam bentuk tabel dan dianalisa secara deskriptif. Data yang diperoleh dari pengamatan jenis tumbuhan yang dianggap menjadi ciri khas kepulauan karimunjawa disajikan dalam bentuk tabel, dihitung kelimpahannya (pohon, tiang, sa- pihan, dan semai) dengan menggunakan rumus kelimpahan [8]:

Kelimpahan $=\frac{\text { Jumlah individu yang ditemukan }}{\text { Luas area yang disampling }}$

Hasil perhitungan kelimpahan kemudian dibuat grafik dan dianalisa secara deskriptif. Apabila jumlah semai, pancang, dan tiang lebih tinggi daripada jumlah pohon, maka kehidupan suatu spesies tumbuhan masih dapat terus berlangsung [9].

\section{HaSil dan PEMbahasan}

Pemanfaatan Tumbuhan oleh Masyarakat Desa Karimunjawa. Desa Karimunjawa mempunyai luas area 4.619 ha yang terdiri 3.334 ha untuk pemukiman penduduk dan lahan garapan dan 1.285 ha hutan lindung (cagar alam) [10]. Jumlah penduduk Desa Karimunjawa ada 4.137 jiwa yang sebagian besar bermukim di tepi pantai. Di Desa Karimunjawa terdapat 1.327 kepala keluarga (Statistik Kecamatan Karimunjawa, [11]).

Penduduknya terdiri atas bermacam-macam suku (etnik) yaitu Jawa, Madura, dan Sunda [12] dengan mata pencarian utama sebagai petani, pembuat industri rumah tangga serta nelayan. Selain itu mata pencaharian alternatif yang lain adalah pengrajin, kuli batu, pengajar, Pegawai Negeri Sipil, buruh, karyawan swasta bahkan ada penduduk yang merantau keluar dari kepulauan Karimunjawa.

Pertanian lebih diutamakan untuk tanaman pangan pokok dan tanaman perdagangan. Sebagai petani dan nelayan, penduduk banyak berinteraksi dengan tumbuh-tumbuhan, baik tumbuhan budidaya maupun tumbuhan liar dari hutan. Besarnya pemanfaatan tumbuh-

\begin{tabular}{|c|c|c|c|c|c|}
\hline \multirow[b]{2}{*}{$\begin{array}{l}\text { Pekerjaan } \\
\text { Jenis }\end{array}$} & \multicolumn{5}{|c|}{ Jumlah responden } \\
\hline & & $\begin{array}{l}\text { Pengguna tumbuhan } \\
\text { dari alam (etnik) }\end{array}$ & $\begin{array}{c}\text { Membudidayakan } \\
\text { tumbuhan etnik }\end{array}$ & $\begin{array}{l}\text { Mengetahui tumbuhan } \\
\text { khas Karimunjawa }\end{array}$ & $\begin{array}{l}\text { Memanfaatkan } \\
\text { tumbuhan khas }\end{array}$ \\
\hline Nelayan & 31 & 20 & 15 & 26 & 12 \\
\hline Kuli batu & 2 & - & - & - & - \\
\hline Pedagang & 5 & 4 & 2 & 2 & 1 \\
\hline Merantau & 1 & - & - & 1 & - \\
\hline Petani & 16 & 12 & 8 & 13 & 5 \\
\hline Pengajar & 1 & 1 & 1 & 1 & - \\
\hline Pegawai Negeri Sipil & 7 & 2 & 2 & 7 & 1 \\
\hline Buruh & 4 & 2 & - & 1 & - \\
\hline Pengrajin & 4 & 3 & 2 & 4 & 3 \\
\hline Karyawan swasta & 3 & 1 & 1 & 3 & 1 \\
\hline Lainnya & 16 & 5 & 5 & 13 & 5 \\
\hline Jumlah & 90 & 50 & 36 & 73 & 28 \\
\hline
\end{tabular}
an oleh masyarakat berdasarkan hasil kuisioner ditunjukkan pada Gambar 2.

TABEL 1

Jumlah Penduduk yang MemanfaAtKan Tumbuhan DaRi Alam Berdasarkan Hasil Kuisioner 


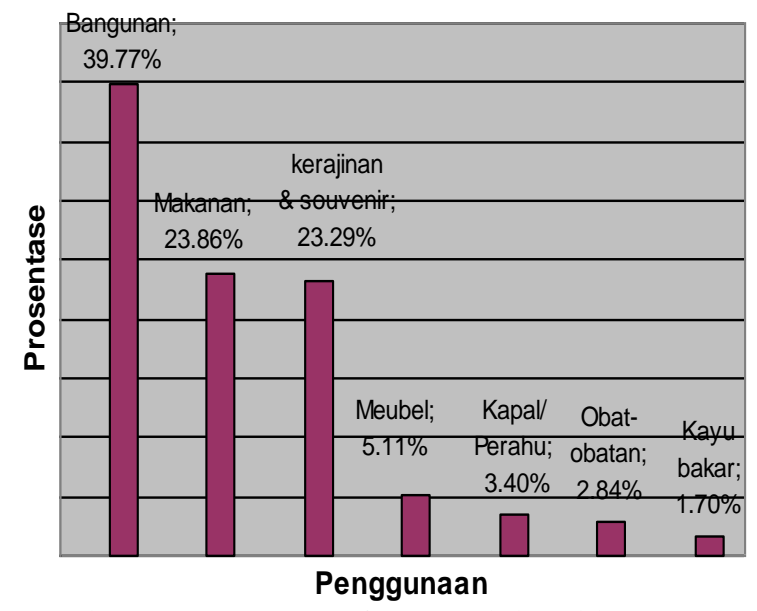

Gambar 2. Prosentase Pemanfaatan Tumbuhan oleh Masyarakat Desa Karimunjawa

Tumbuhan sebagai bahan makanan umumnya adalah tumbuhan budidaya karena tidak banyak tumbuhan liar yang dapat dijadikan bahan makanan. Masyarakat juga banyak yang memanfaatkan tumbuhan sebagai bahan pembuatan kerajinan dan souvenir karena di Karimunjawa terdapat tumbuhan khas baik untuk kerajinan dan souvenir.

Berdasarkan pengamatan yang telah dilakukan, ditemukan 39 spesies tumbuhan yang dimanfaatkan oleh masyarakat setempat yang terdiri dari 21 spesies tumbuhan liar dan 18 spesies tumbuhan budidaya (di kebun atau pekarangan). Beberapa spesies tumbuhan yang tumbuh di pekarangan adalah pisang (Musa paradisiaca L) dan tanaman palawija [13]. Tumbuhan yang banyak dijumpai di kebun adalah jambu mete (Anacardium occidentale L.), jambu (Psidium guajava), padi (Oryza sativa) dan kelapa (Cocos nucifera).

Tumbuhan sebagai Bahan Makanan. Makanan adalah kebutuhan primer yang harus tercukupi untuk kelangsungan hidup setiap makhluk hidup. Berdasarkan pengamatan diketahui bahwa tumbuhan yang dimanfaatkan sebagai bahan makanan sebayak 18 spesies $(46,10 \%)$ yang terdiri tumbuhan liar dan budidaya. Desa Karimunjawa dikelilingi oleh hutan hujan tropis dataran rendah, namun tidak banyak tumbuhan liar yang dapat dimanfaatkan masyarakat sebagai bahan makanan. Beberapa jenis tumbuhan yang dapat dimanfaatkan sebagai bahan makanan disajikan pada Tabel 2. Masyarakat yang hidup di sekitar Taman Nasional Gunung Halimun Jawa Barat juga memanfaatkan sentul (Sandoricum koetjape) sebagai bahan makanan [14]. Namun saat ini masyarakat Karimunjawa sukar mendapatkan buah-buahan tersebut karena telah habis dimakan Macaca fasikularis.

Tumbuhan yang dikembangkan untuk pertanian bukan tanaman pangan pokok seperti padi melainkan Cengkeh, Kelapa Kopi dan Randu, dan tumbuhan pangan seperti jagung, Ketela Pohon, Ubi Jalar, Kacang Tanah, Kedelai dan Kacang Wijen serta jenis tumbuhan hortikultura yaitu mangga, pisang, nangka, sukun, nanas, jeruk, kedondong, jambu air dan jambu monyet [1].
Jambu mete, pisang, mangga, pepaya, nangka dan kelapa banyak dijumpai di kebun-kebun penduduk, sedangkan ketela pohon, ketela rambat, jeruk, dan jambu banyak ditemui di pekarangan dan ladang.

Tumbuhan sebagai Bahan Bangunan. Rumah merupakan kebutuhan primer. Oleh karena itu, masyarakat sangat membutuhkannya sebagai tempat berlindung. Untuk membuat rumah atau bangunan yang lain, masyarakat banyak memanfaatkan tumbuhan dari hutan. Tumbuh-tumbuhan tersebut dimanfaatkan sebagai tiang penyangga bangunan, atap rumah, dan papan.

Berdasarkan Tabel 3 diketahui bahwa ada 16 spesies tumbuhan $(43,59 \%)$ sebagai bahan bangunan yang merupakan tumbuhan liar dan tumbuhan budidaya. Tumbuhan-tumbuhan yang dimanfaatkan masyarakat sebagai bahan bangunan merupakan tumbuhan yang mempunyai kayu yang bersifat tahan lama [15]. Laban (Vitex pubescens) merupakan kayu yang keras dan tahan lama, serta sangat baik untuk perabotan rumah tangga dan bangunan. Di Maluku, Jambon (Vitex copasus) dimanfaatkan untuk membuat perahu karena kayunya tahan terhadap air laut dan tidak mudah retak. Kayu Gondorio (Bouea macrophylla) tidak begitu baik kualitasnya namun biasanya dimanfaatkan untuk membuat bangunan yang berukuran kecil. Kayu Kliko (Phylanthus boxifolius) baik digunakan untuk pembuatan arang dan kayu bakar namun juga baik digunakan untuk perabotan rumah tangga. Kayu sentul (Sandoricum koetjape) mempunyai penampilan yang indah, baik digunakan untuk perabotan rumah tangga dan bangunan.

Tumbuhan sebagai Bahan Kerajinan dan Meubel. Masyarakat Desa Karimunjawa bermata pencaharian sebagai pengrajin. Tahun 1994, masyarakat mulai banyak yang memanfaatkan tumbuhan dari alam sebagai bahan kerajinan. Bedasarkan hasil kuisioner terdapat 3 spesies tumbuhan untuk bahan kerajinan $(7,7 \%)$ yaitu pada Tabel 4. Menurut Karyanto (petugas Taman Nasional Karimunjawa) tumbuhan yang banyak dimanfaatkan sebagai bahan kerajinan adalah tumbuhan khas kepulauan Karimunjawa, yaitu Dewadaru (Fragraea elliptica), Kalimasada (Cordia subcordata), dan Setigi (Pemphis acidula) (wawancara Karyanto, 28 Mei 2007, pkl 16.00 WIB). Hasil kerajinan dijadikan sebagai souvenir bagi wisatawan pengunjung kepulauan Karimunjawa. Tahun 2005 banyak masyarakat memanfaatkan Setigi (Pemphis acidula) untuk bonsai. Setigi (Pemphis acidula) yang diambil dari hutanhutan pantai pulau Karimunjawa. Menurut Heyne [15] Dewadaru (Fragraea elliptica), Kalimasada (Cordia subcordata), dan Setigi (Pemphis acidula) merupakan tumbuhan yang mempunyai kayu yang kuat dan tahan lama sehingga baik digunakan sebagai bahan bangunan dan peralatan rumah tangga. 
TABEL 2

TUMBUHAN SEBAGAI BAHAN MAKANAN

\begin{tabular}{|c|c|c|c|}
\hline Nama lokal & Nama ilmiah & Bagian yang dimanfaatkan & Status (budidaya/liar) \\
\hline Gondorio & Bourea macrophylla & buah & liar \\
\hline Manggisan & Calophylum soulatri & buah & liar \\
\hline Padi & Oryza sativa & buah & budidaya \\
\hline Jambu mete & Anacardium occidentale & buah & budidaya \\
\hline Mangga & Mangifera indica & buah & budidaya \\
\hline Pepaya & Carica papaya & buah & budidaya \\
\hline Kelapa & Cocos nucifera & buah & budidaya \\
\hline Ketela rambat & Ipomoea batatas & umbi & budidaya \\
\hline Anggur & Vitis vinifera & buah & budidaya \\
\hline Sentul & Sandoricum koetjape & buah & liar \\
\hline Pisang & Musa paradisiaca & buah & budidaya \\
\hline Nangka & Artocarpus integra & buah & budidaya \\
\hline Jengkol & Pithecolobium ellipticum & buah & budidaya \\
\hline Cengkeh & Eugenia aromatica & daun & budidaya \\
\hline Jeruk & Citrus spec & buah & budidaya \\
\hline Langsep & Dysoxylum ramiflorum & buah & budidaya \\
\hline Ketela pohon & Manihot utilissima & umbi & budidaya \\
\hline Palawija & - & daun & budidaya \\
\hline
\end{tabular}

TABEL 3

TUMBUHAN SEBAGAI BAHAN BANGUNAN

\begin{tabular}{|c|c|c|c|}
\hline Nama lokal & Nama ilmiah & Bagian yang dimanfaatkan & Status (budidaya/ liar) \\
\hline Gondorio & Bouea macrophylla & Batang & liar \\
\hline Manggisan & Calophylum soulatri & Batang & liar \\
\hline Jambon & Vitex copasus & Batang & liar \\
\hline Semedang & - & Batang & liar \\
\hline Dewadaru & Fragraea elliptica & Batang & liar \\
\hline Kelapa & Cocos nucifera & Batang & budidaya \\
\hline Nyamplungan/Bintangur & Calophyllum inophyllum & Batang & liar \\
\hline Terangkil & - & Batang & liar \\
\hline Sentul & Sandoricum koetjape & Batang & liar \\
\hline Lempeni & Ardisia humilis & Batang & liar \\
\hline Nangka & Artocarpus integra & Batang & Budidaya \\
\hline Rokok-rokok & Melastoma afline & Batang & liar \\
\hline Jati & Tectona grandis & Batang & liar \\
\hline Laban & Vitex pubescens & Batang & liar \\
\hline Kliko & Phylanthus boxifolius & Batang & liar \\
\hline
\end{tabular}

TABEL 4

TUMBUHAN SEBAGAi BAHAN KERAJINAN DAN MEUBEL

\begin{tabular}{llcc}
\hline Nama lokal & Nama ilmiah & Bagian yang dimanfaatkan & Status(budidaya/ liar) \\
\hline Dewadaru & Fragraea elliptica & Batang & liar \\
Setigi & Pemphis acidula & Batang & liar \\
Kalimasada & Cordia subcordata & Batang & liar \\
jambon & Vitex copasus & Batang & liar \\
Semedang & - & Batang & liar \\
Wahong & - & Batang & liar \\
Kapasan & Crypteronia paniculata & & liar \\
Nangka & Artocarpus integra & Batang & Budidaya \\
Jambu & Psidium guajava & Batang & Budidaya \\
\hline
\end{tabular}

Dewadaru (Fragraea elliptica) yang dimanfaatkan masyarakat sebagai bahan kerajinan, dahulu diambil dari hutan cagar alam (konservasi). Sekarang tidak ditemui Dewadaru di hutan cagar alam [13]. Spesies Ka- limasada (Cordia subcordata) sudah tidak ditemui dalam kondisi yang alami di habitat aslinya. Kalimasada yang ditemukan merupakan hasil penanaman kembali oleh masyarakat setempat dan dinas kehutanan. 
Tumbuhan yang digunakan sebagai bahan pembuatan meubel ada 7 spesies $(17,90 \%)$ sebagaimana tertera pada Tabel 4. Meubel tersebut dipasarkan untuk penduduk lokal dan hanya diproduksi juka ada permintaan. Tumbuh-tumbuhan tersebut banyak dipilih sebagai bahan pembuatan meubel dan kerajinan karena mempunyai kualitas kayu yang baik [15].

Salah satu faktor pemicu munculnya banyak pengrajin di Karimunjawa adalah karena kerajinan dianggap berprospek baik dibandingkan bertani dan nelayan. Hal ini menyebabkan terancamnya keberadaan beberapa spesies tumbuhan yang terdapat di Karimunjawa.

Tumbuhan sebagai Bahan. Untuk memenuhi kebutuhan obat-obatan, masyarakat tidak banyak memanfaatkan tumbuhan dari alam. Berdasarkan Tabel 5 diketahui terdapat 6 spesies tumbuhan $(12,80 \%)$ yang pernah dimanfaatkan sebagai bahan obat-obatan.

Masyarakat suku Muyu di Papua memanfaatka pepaya (Carica papaya) sebagai bahan obat-obatan [16]. Menurut Heyne [15], daun Kalimasada dapat dimanfaatkan untuk menghindari dan mengobati gigitan binatang berbisa. Di Taman Nasional Karimunjawa terdapat 120 spesies tumbuhan dari 14 famili yang berpotensi sebagai tumbuhan obat, namun hanya beberapa spesies tumbuhan yang dimanfaatkan oleh masyarakat. Tumbuhan-tumbuhan tersebut tersebar di hutan tropis, hutan pantai, dan pekarangan rumah penduduk.

Hasil kuisioner dari 90 orang responden, diketahui terdapat 50 orang $(55 \%)$ yang memanfaatkan tumbuhtumbuhan dari alam dan 36 orang (44\%) yang membudidayakan tumbuhan yang mereka manfaatkan. Hal ini menunjukkan bahwa masih rendahnya tingkat kesadaran masyarakat tentang keberadaan tumbuhan etnik. Tumbuhan tersebut dibudidayakan dengan cara ditanam di ladang, kebun, dan pekarangan rumah. Sebagian besar masyarakat yang memanfaatkan tumbuhan dari alam adalah yang bermatapencaharian sebagai petani dan nelayan. Sebagai petani, masyarakat banyak berinteraksi dengan tumbuhan dan sebagai nelayan, masyarakat memanfaatkan tumbuhan sebagai bahan pembuatan kapal.

Profil Tumbuhan Khas Kepulauan Karimunjawa. Tumbuhan khas Taman Nasional Karimunjawa adalah Dewadaru (Fragraea elliptica) yang merupakan vegetasi hutan hujan tropis dataran rendah, Kalimasada (Cordia subcordata), dan Setigi (Pemphis acidula) yang merupakan vegetasi hutan pantai.

Tidak semua gugusan pulau di kepulauan Karimunjawa mempunyai ketiga spesies tumbuhan tersebut. Contohnya adalah Dewadaru (Fragraea elliptica), tumbuhan ini hanya ditemukan di pulau Karimunjawa.

Dewadaru (Fragraea elliptica) merupakan salah satu dari tiga spesies tumbuhan yang menjadi ciri khas kepulauan Karimunjawa. Habitat tumbuhan ini adalah di hutan tropis dataran rendah [13].

Dewadaru mempunya ciri-ciri: berdaun tunggal, daun bentuk bulat lonjong (ellips) dengan ujung merun- cing, tipis, licin, dan bertangkai pendek. Duduk daun berseling berhadapan di bagian ujung (terminal) cabang. Bagian atas daun berwarna hijau tua dan bagian bawah berwarna lebih terang. Tulang daun menyirip (Gambar 3). Batang berwarna coklat tua sampai kelabu dengan permukaan kasar. Tipe percabangannya monopodial, tinggi mencapai 7 meter dengan tajuk yang sangat rimbun. Pada saat dilakukan pengamatan, tidak ditemukan bunga, buah atau biji.

Lokasi yang masih dapat dijumpai Dewadaru alami adalah daerah Alang-alang, Ujung Gelam, dan Legon Lele. Dewadaru di Ujung Gelam ditemukan 15 individu dan di Alang-Alang ditemukan 48 individu (Tabel 6). Lokasi Legon Lele juga dijumpai satu individu Dewadaru. Jumlah Dewadaru di Alang-Alang lebih tinggi dari pada di dua lokasi lainnya karena tingginya kesadaran penduduk tentang pentingnya keberadaan Dewadaru di alam. Lokasi Ujung Gelam, jumlah Dewadarunya lebih rendah daripada di AlangAlang karena intensitas pengambilan Dewadaru di lokasi ini relatif tinggi dibandingkan dengan di daerah Alang-Alang. Beberapa semai Dewadaru di sekitar induk tidak dijumpai lagi. Lokasi Legon Lele, hanya ditemukan satu individu Dewadaru. Hal ini disebabkan oleh kondisi lingkungan yang tidak sesuai untuk Dewadaru karena Legon Lele merupakan dataran rendah yang terpengaruh pasang surut dan hanya sesuai untuk tumbuhan yang berekosistem hutan pantai. Dewadaru merupakan spesies tumbuhan yang hidup di ekosistem hutan hujan tropis sehingga kurang sesuai dengan lingkungan tempat tumbuhnya.

Menurut Nurhadi (Pengrajin di Desa Karimunjawa) sejak tahun 1982, Dewadaru jarang dijumpai di alam. Tahun 1985, di pulau Parang ditemukan 4 bongkah Dewadaru, di pulau Menyawaan 3 bongkah, dan di pulau Kembar ditemukan 1 bongkah (Wawancara Nurhadi, jumat 1 juni 2007).

Jumlah Dewadaru berstatus pancang berjumlah lebih tinggi dibandingkan dengan tingkat status yang lain (pohon, tiang, dan semai). Jumlah Dewadaru ada 64 individu dengan jumlah pohon 9 individu, tiang 6 individu, sebanyak 33 individu, dan semai 16 individu. Hal ini menunjukkan bahwa kondisi Dewadaru di habitat alaminya relatif baik. Terdapat individu Dewadaru di setiap tingkatan menunjukkan bahwa regenerasi Dewadaru tidak terhambat dan dapat dipertahankan keberadaannya. Berdasarkan Molles [10], jika jumlah semai, pancang, dan tiang lebih tinggi daripada jumlah pohon suatu spesies maka dapat dikatakan spesies tersebut kemungkinan dapat dipertahankan di habitatnya karena kondisi lingkungan yang kompleks dan adanya kompetisi menyebabkan tidak semua semai tumbuh menjadi pohon.

Peningkatan sektor pariwisata di kepulauan Karimunjawa menyebabkan tingginya konsumsi kerajinan dari kayu Dewadaru sehingga secara tidak langsung menyebabkan penurunan populasi Dewadaru. Dewadaru merupakan kayu yang mempunyai banyak kelebihan dibandingkan kayu yang lain sehingga dijadikan sebagai ciri khas kepulauan Karimunjawa. (Wawancara Nurhadi, Jumat 1 Juni,2007). 
TABEL 5

TUMBUHAN SEBAGAI BAHAN OBAT-OBATAN

\begin{tabular}{cllcc}
\hline No & Nama lokal & \multicolumn{1}{c}{ Nama ilmiah } & Bagian yang dimanfaatkan & Status (budidaya/liar) \\
\hline 1 & Dewadaru & Fragraea elliptica & Batang & liar \\
2 & Setigi & Pemphis acidula & Batang & liar \\
3 & Kalimasada & Cordia subcordata & Batang & liar \\
4 & Bangon & Paniculum stagninum & Daun & liar \\
5 & Semedang & - & Daun & liar \\
6 & Pepaya & Carica papaya & Daun & Budiadaya \\
\hline
\end{tabular}

TABEL 6

DENSITAS SPESIES DEWADARU (FRAGRAEA ELLIPTICA) DI DESA KARIMUNJAWA

\begin{tabular}{|c|c|c|c|c|c|c|}
\hline \multirow{2}{*}{ No } & \multirow{2}{*}{ Lokasi } & \multicolumn{4}{|c|}{ Jumlah tingkat } & \multirow{2}{*}{ Total } \\
\hline & & Pohon & Tiang & Pancang & Semai & \\
\hline 1 & Ujung Gelam & 3 & 4 & 8 & - & 15 \\
\hline 2 & Alang-Alang & 5 & 2 & 25 & 16 & 48 \\
\hline \multirow[t]{2}{*}{3} & Legon Lele & 1 & - & - & - & 1 \\
\hline & Jumlah & 9 & 6 & 33 & 16 & 64 \\
\hline
\end{tabular}

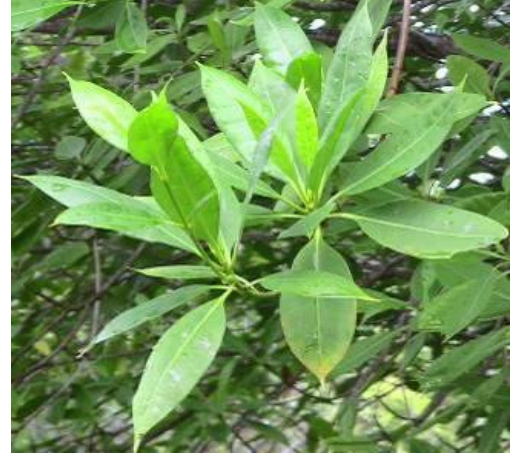

Gambar 3. Morfologi Daun Dewadaru (Fragraea elliptica)

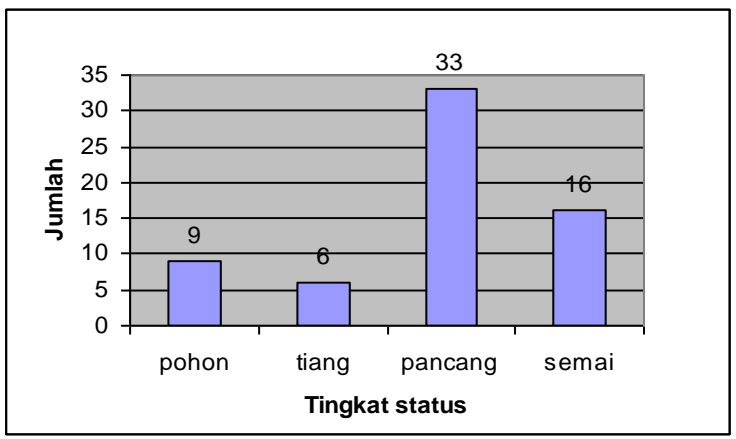

Gambar 4. Jumlah Spesies Dewadaru (Fragraea elliptica)

Tumbuhan lain yang dijadikan sebagai ciri khas kepulauan Karimunjawa adalah Setigi (Pemphis acidula) [13]. Tumbuhan ini berhabitat di hutan pantai, di atas batu karang dan berpasir .

Setigi yang ditemukan di pulau karimunjawa mempunyai ciri-ciri: berupa pohon dengan tinggi hingga 4 meter. Batang berwarna coklat kemerahan dengan percabangan monopodial, bertajuk rimbun. Daun tunggal, berbentuk oval berukuran kecil, duduk daun bersilang berhadapan dan mempunyai daun penumpu (Gambar 5). Tidak ditemukan bunga, buah, maupun biji Setigi pada saat dilakukan pengamatan.

Setelah dilakukan pengamatan, tumbuhan ini hampir sudah tidak lagi ditemukan di daerah vegetasi hutan pantai di sepanjang pantai Karimunjawa. Berdasarkan pengamatan yang dilakukan, Setigi hanya ditemukan di pantai Ujung Gelam. Di daerah Ujung Gelam

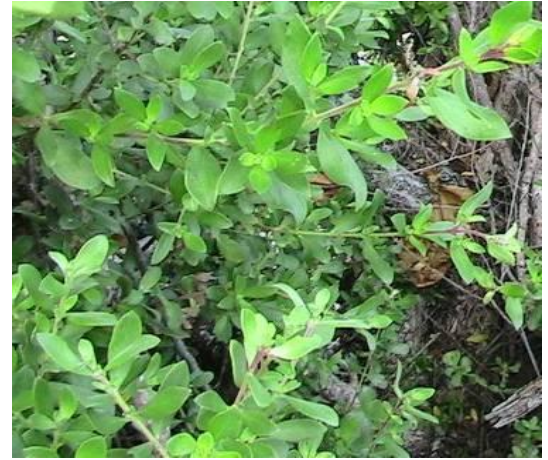

Gambar 5. Morfologi Daun Setigi (Pemphis acidula)

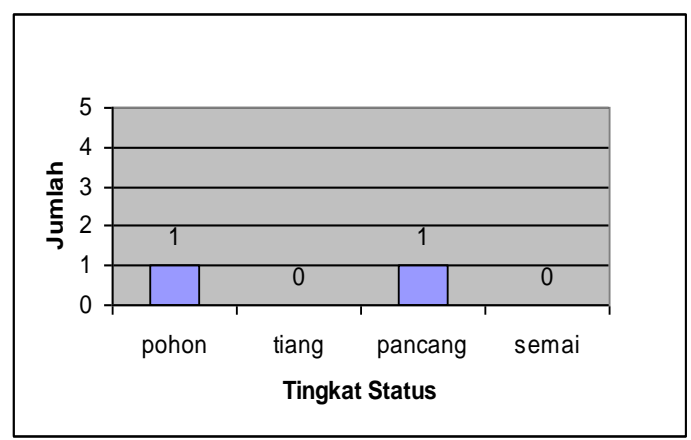

Gambar 6. Jumlah Spesies Setigi (Pemphis acidula) per Tingkat Status

hanya ditemukan dua individu yang masih hidup dengan status pohon 1 individu dan status pancang 1 individu (Gambar 6).

Kondisi Setigi di Desa Karimunjawa sangat menghawatirkan karena tidak satu pun ditemukan semai Setigi di habitat alaminya. Hal ini dapat menghambat kelangsungan hidup di habitat aslinya sehingga akhirnya menyebabkan kepunahan skala lokal [17].

Aktivitas pengambilan Setigi melalui pencangkokan (Gambar 7) yang dilakukan oleh masyarakat memberikan kontribusi terhadap penurunan populasi Setigi di Desa Karimunjawa. Selain mencangkok, masyarakat juga menebang pohon Setigi. Di sekitar pohon hidup ditemukan batang sisa penebangan Setigi dengan diameter yang bervariasi. Di sepanjang transek juga ditemukan batang sisa penebangan Setigi yang berdiameter $10-40 \mathrm{~cm}$. 
Faktor yang sangat berperan terhadap kepunahan Setigi di pulau Karimunjawa adalah cara pengambilan Setigi yang kurang tepat. Sebagian besar penduduk mengambil Setigi beserta akarnya tanpa meninggalkan sisa induknya sehingga regenerasi Setigi menjadi terputus, karena perkembangbiakan Setigi menggunakan biji. Apabila tidak terdapat pohon sebagai penghasil biji, maka tidak diperoleh semai-semai Setigi yang baru dan akhirnya dapat menurunkan populasinya.

Setigi (Pemphis acidula) merupakan tumbuhan vegetasi hutan pantai yang bukan termasuk dalam kawasan konservasi sehingga sukar dilakukan pengontrolan populasi Setigi di alam. Masyarakat akan dapat memanfaatkan Setigi sesuai keinginan tanpa ada larangan karena daerah pantai merupakan lahan masyarakat.

Menurut Biki (pengrajin dan pembuat bonsai di Desa Karimunjawa) pembuatan bonsai Setigi mulai diminati sejak tahun 2005 dan sampai saat ini (tahun 2007) pembuatan bonsai masih dilakukan (Gambar 8).

Hal tersebut mengakibatkan penurunan populasi Setigi sehingga masyarakat harus mendapatkan Setigi dari pulau Parang, pulau Menjangan Besar, pulau Menjangan Kecil, dan pulau Nyamuk untuk memenuhi kebutuhannya (Wawancara Biki, tanggal 1 Juli 2007).

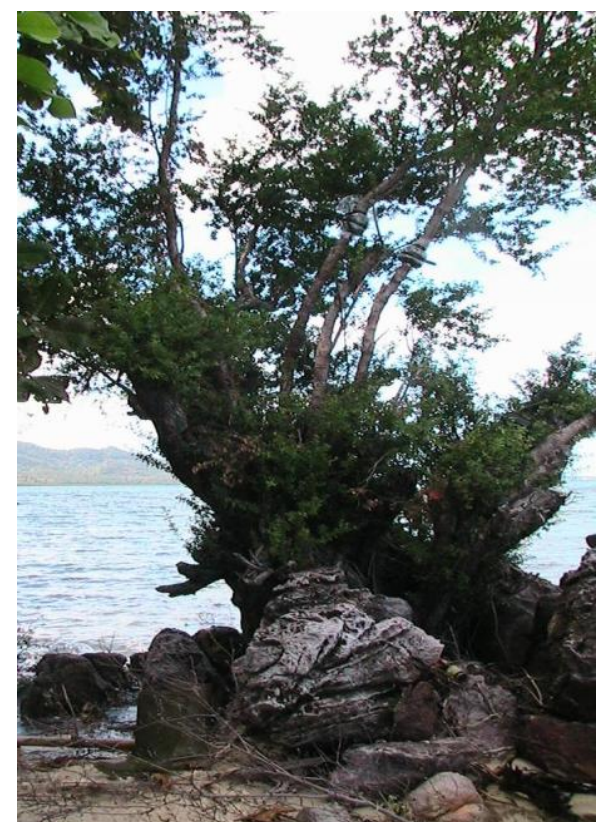

(a)

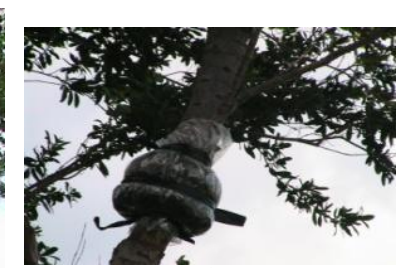

(b)

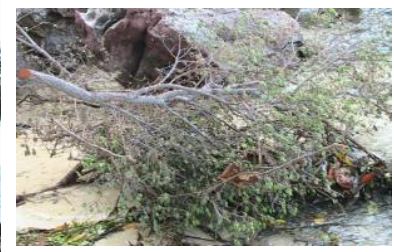

(c)

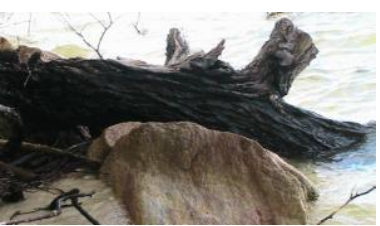

(d)

Gambar 7. Setigi (Pemphis acidula) di Ujung Gelam (a) Pohon Setigi di Atas Karang, (b) Pencangkokan pada Pohon Setigi, (c) dan (d) Sisa Kegiatan Penebangan Pohon Setigi

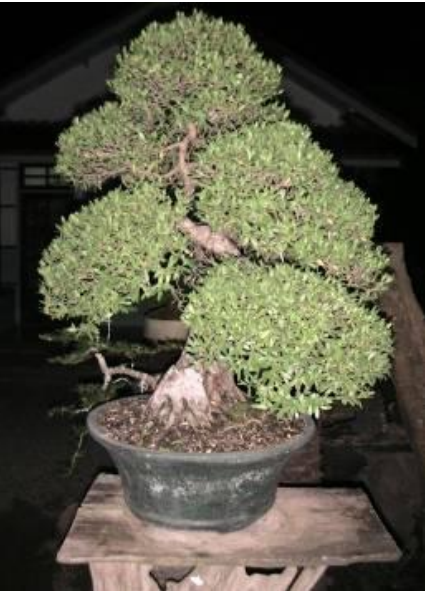

Gambar 8. Bonsai Pohon Setigi (Pemphis acidula)

Setigi (Pemphis acidula) merupakan tumbuhan vegetasi hutan pantai yang bukan termasuk dalam kawasan konservasi sehingga sukar dilakukan pengontrolan populasi Setigi di alam. Masyarakat akan dapat memanfaatkan Setigi sesuai keinginan tanpa ada larangan karena daerah pantai merupakan lahan masyarakat.
Menurut Biki (pengrajin dan pembuat bonsai di Desa Karimunjawa) pembuatan bonsai Setigi mulai diminati sejak tahun 2005 dan sampai saat ini (tahun 2007) pembuatan bonsai masih dilakukan (Gambar 8). Hal tersebut mengakibatkan penurunan populasi Setigi sehingga masyarakat harus mendapatkan Setigi dari pulau Parang, pulau Menjangan Besar, pulau Menjangan Kecil, dan pulau Nyamuk untuk memenuhi kebutuhannya (Wawancara Biki, tanggal 1 Juli 2007).

Kalimasada (Cordia subcordata) juga merupakan salah satu tumbuhan yang menjadi ciri khas kepulauan Karimunjawa [13].

Berdasar pengamatan yang dilakukan, ciri-ciri Kalimasada adalah berhabitus pohon, tinggi mencapai 7 meter. Daunnya berbentuk bulat telur, bagian atas daun berwarna hijau mengkilat dan bagian bawah daun berwarna lebih terang. Bunga Kalimasada berwarna orange berada di bagian ujung percabangan dan pada daun aksiler.

Berdasarkan pengamatan yang telah dilakukan, tidak ditemukan Kalimasada di habitat aslinya (hutan pantai). Menurut keterangan masyarakat setempat, saat ini tidak ditemukan lagi pohon Kalimasada yang tumbuh secara alami di kawasan pulau Karimunjawa 
tetapi masih mungkin ditemukan di gugusan pulau Karimunjawa yang lain.

Tahun 2005 dilakukan penanaman sebanyak 500 batang bibit Kalimasada oleh masyarakat dan dinas kehutanan di desa Nyamplungan sepanjang $1,5 \mathrm{~km}$. Bibit pohon Kalimasada diperoleh dengan menyemaikan biji yang berasal dari pohon Kalimasada di depan kantor Taman Nasional Karimunjawa Gambar 9). Saat ini tinggi Kalimasada yang ditanam tahun 2005 yang sudah mencapai 2 meter dan bersatus pancang. Penanaman ini ditujukan untuk menjaga kelestarian Kalimasada di alam.

Banyak taman nasional yang didirikan untuk melindungi spesies-spesies yang terancam punah. Namun, terbentuknya kawasan perlindungan seringkali belum menjamin kelestarian spesies meskipun perlindungan tersebut telah diperkuat dengan landasan hukum. Seringkali kawasan perlindungan tersebut ditetapkan setelah sebagian besar dari populasi spesies yang terancam sudah sangat berkurang akibat kehilangan habitat, perusakan habitat, fragmentasi habitat, maupun perburuan yang berlebihan. Dalam keadaan demikian, spesies dapat berkurang dengan cepat menuju kepunahan. Sementara itu, individu di luar kawasan perlindunganpun masih belum terlindungi [17].

Suatu spesies dianggap telah punah dalam skala lokal apabila tidak ada lagi individu yang ditemukan di tempat mereka dulu berada, tetapi masih ditemukan dan berada di daerah lain di alam. Sementara menurut beberapa ahli biologi konservasi, suatu spesies dikatakan punah secara ekologi apabila terdapat dalam jumlah yang sangat kecil sehingga efeknya terhadap spesies lain dalam komunitas dapat diabaikan [17].

Pada beberapa populasi, sejumlah kecil individu dapat bertahan beberapa tahun, beberapa dekade, atau bahkan bereproduksi, namun hasil akhirnya adalah kepunahan. Misalnya pada tumbuhan berkayu, individu yang terisolasi dan tidan bereproduksi dapat hidup ratusan tahun, walaupun secara teknis spesies ini tidak punah namun populasinya sudah sangat tidak berkembang dan masa depan spesies tersebut tergantung pada berapa lama individu yang masih hidup dapat bertahan [18].

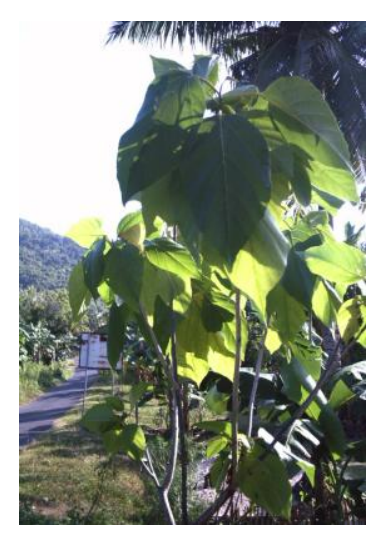

(a)

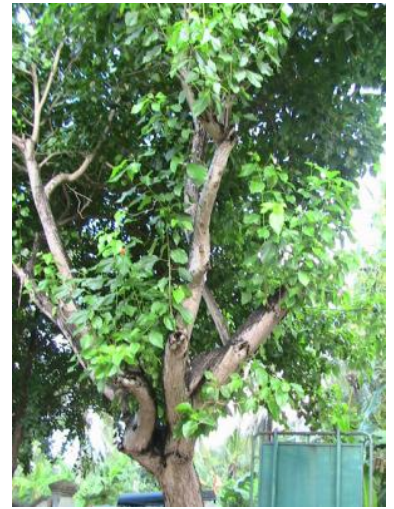

(b)
Gambar 9. Kalimasada (Cordia subcordata) (a) Ditanam pada Tahun 2005 di Sepanjang Tepi Jalan Dukuh Nyamplungan dan (b) di Depan Kantor Taman Nasional Karimunjawa
Hal tersebut dikhawatirkan akan terjadi pada spesies-spesies tumbuhan yang menjadi ciri khas kepulauan Karimunjawa. Tidak ditemukannya lagi spesies-spesies tersebut di kawasan konservasi dapat mengancam keberadaannya di alam. Adanya Taman Nasional Karimunjawa, diharapkan tumbuhan etnik dan khas masih dapat dipertahankan keberadaannya. Taman Nasional didirikan dengan tujuan konservasi, artinya dengan adanya Taman Nasional dapat terjadi kesinambungan antara penelitian, pemanfaatan, dan perlindungan. Konservasi ini penting dilakukan karena bukan hanya ditujukan untuk kelestarian berbagai sumber daya hayati saja tetapi juga mengkonservasi sumber genetik, jenis, dan ekosistem yang penting untuk menjaga kehidupan masa kini dan masa yang akan datang [19].

Pada tahun 1986, kawasan Karimunjawa ditetapkan sebagai kawasan cagar alam laut berdasarkan Surat Keputusan Menteri Kehutanan No.123/Kpts-II/1986 tanggal 9 April 1986. Pada Tahun 1988, kawasan Karimunjawa dinyatakan sebagai Taman Nasional berdasarkan Surat Keputusan Menteri Kehutanan No.161/ Menhut-II/1988, tanggal 23 Februari 1988. Dan pada tahun 1999, kawasan Karimunjawa yang meliputi 22 pulau seluas 111.625 Ha ditetapkan sebagai taman nasional dengan nama Taman Nasional Karimunjawa berdasarkan Surat Keputusan Menteri Kehutanan No. 78/Kpts-II/1999, tanggal 22 Februari 1999 [10].

Adanya Taman Nasional di Kepulauan Karimunjawa memberikan kontribusi terhadap penurunan intensitas penggunaan tumbuhan dari hutan cagar alam, terutama penggunaan tumbuhan kayu sebahai bahan bangunan. Untuk memenuhi kebutuhan pembangunan rumah, masyarakat membeli kayu yang didatangkan dari pulau Kalimantan.

Masyarakat yang mempunyai kebun di luar daerah cagar alam biasanya masih dapat memanfaatkan tumbuhan dari kebunnya. Dari kebun tersebut masyarakat mengambil kayu sebagai bahan bangunan, meubel, kerajinan, dan kayu bakar. Selain tumbuhan yang digunakan kayunya, di kebun masyarakat juga ditanami dengan tumbuhan pangan seperti jambu mete, kelapa, nangka, dan lain-lain.

Hampir semua jenis tumbuhan yang berpotensi sebagai bahan bangunan masih dapat dijumpai dengan jumlah yang melimpah di wilayah cagar alam seperti Bouea macrophylla, Calophylum soulatri, Vitex copasus, Terangkil, Fragraea elliptica, Cocos nucifera, Calophyllum inophyllum, Sandoricum koetjape, Ardisia humilis, Semedang, Artocarpus integra, Melastoma afline, Tectona grandis, Vitex pubescens, Phylanthus boxifolius. Namun untuk spesies tumbuhan yang tidak tumbuh di wilayah cagar alam (konservasi) mulai terancam keberadaannya, contohnya adalah Dewadaru (Fragraea elliptica), Setigi (Pemphis acidula), dan Kalimasada (Cordia subcordata) [13].

\section{KESIMPULAN}

Masyarakat Desa Karimunjawa memanfaatkan tumbuhan sebagai bahan bangunan $(39,77 \%)$, bahan makanan (23,86\%), kerajinan dan souvenir (23,29\%), meubel $(5,11 \%)$, kapal/perahu $(3,40 \%)$, obat-obatan 
$(2,84 \%)$, dan kayu bakar $(1,70 \%)$. Terdapat 39 spesies tumbuhan yang dimanfaatkan oleh masyarakat Desa Karimunjawa. Diantara tumbuhan tersebut terdapat tiga spesies tumbuhan khas kepulauan Karimunjawa yaitu Dewadaru (Fragraea elliptica), Setigi (Pemphis acidula), dan Kalimasada (Cordia subcordata). Hasil pengamatan menunjukkan bahwa di Desa Karimunjawa ditemukan 64 individu Dewadaru yang berstatus pohon, tiang, pancang, dan semai serta dua individu Setigi yang berstatus pohon dan pancang. Tidak dijumpai Kalimasada yang tumbuh alami di habitatnya, yang dijumpai adalah Kalimasada hasil tanaman penduduk dan dinas kehutanan di sepanjang tepi jalan Nyamplungan.

\section{DAFTAR PUSTAKA}

[1] Atkins, K.. 2004. Tourism and Development in the Karimunjawa National Park. Program ACICIS FISIP UMM. Malang

[2] Anonim. 2005. Classification of the species Fragraea lanceolata. http://www.omne-vivum.com/a/263.htm

[3] Kershaw, KA. 1973. Quantitative an Dynamic Plant Ecology. Second Edition Butter dan Tanner, London

[4] Tsehaye Y. dan Kebebew F. 2006. Diversity and cultural use of Enset (Enset ventricosum (Welw.) Cheesman) in Bonga in situ Conservation Site", Ethiopia. Ethnobotany Research \& Applications. Volume 4, halaman 147-157. http://www.ethnobotanyjournal.org/vol4/i1547-3465-04-147

[5] Anonymous. 2006. Kepulauan Karimunjawa. BackpackingIndonesia.com. Http://www. BackpackingIndonesia.com

[6] Lynch, S,J.F, Hoelnsteiner, R.M\&Cover, C.L. 1974. Data Gathering by social Science. Quezon City. Philipine Social Science Council.

[7] Iskandar, J. 2003. Studi Etnobotani Pemanfaatan Jenis-Jenis Tumbuhan Sebagai Bahan Obat Tradisional Oleh Masyarakat di Desa Cibunar Kecamatan Rancakalong Kabupaten Sumedang-Jawa Barat. Jurnal Biotika, Vol.2 No.1 Juni 2003 Hal: 22-23.
[8] Siregar, M.B.E. 2005. Inventarisasi Jenis Palem (Arecaceae) Pada Kawasan Hutan Dataran Rendah Di Stasiun Penelitian Sikundur (Kawasan Ekosistem Leuser) Kab. Langkat. Repository USU. Jurusan Kehutanan Fakultas Pertanian Universitas Sumatera Utara.

[9] Soerianegara, I. dan A. Indrawan. 1992. Ekologi hutan Indonesia. World Research Institute. Departemen Manajemen Hutan, Fakultas Kehutanan IPB, Bogor.

[10] Molles, C. Manuel. 1999. Ecology. Mc. Graw Hill Company. USA.

[11] Keputusan menteri kehutanan. 2005. Taman Nasional Karimunjawa.Http://www.ditjenphka.go.id/kawasan/tn/Taman\%20Nas ional\%20Karimun\%20Jawa

[12] Statistik desa Karimunjawa, 2006. Karimunjawa, Jepara

[13] Anonymous. 2007. Jenis Kayu Bertuah dan Gunanya. Free Forum Hosting.Forumer.com. Http:// www.topmdi.com/java/doc/KAYU.

[14] Anonymous. 2006. Kepulauan Karimunjawa. BackpackingIndonesia.com..Http://www.BackpackingIndonesia.com

[15] Rahayu, M. dan Harada, K. 2004. Peran Tumbuhan dalam Kehidupan tradisional Masyarakat Lokal di Taman Nasional Gunung Halimun Jawa Barat. Berita Biologi. Volume 7 Nomor 1 Halaman 17-23.

[16] Heyne, K. 1987. Tumbuhan Berguna Indonesia. Terjemahan oleh Badan Litbang Kehutanan Tahun 1987. Departemen Kehutanan: Jakarta.

[17] Susiarti, S. dan Rahayu D.R. 2003. Pemanfaatan Tumbuhan Dalam Kehidupan Masyarakat Suku Muyu di Desa Soa dan Sekitarnya, Merauke, Papua. Berita Biologi. Volume 6 Nomor 5 halaman 705-711.

[18] Primack, B.R., Supriatna, J., Indrawan, M., Kramadibrata. P. 1998. Biologi Konservasi. Yayasan Obor Indonesia; Jakarta.

[19] Gentry, A.H. 1986. Endemism in Tropical Versus Temperate Plant Communities. Dalam M.E. Soule (ed), Conservation Biology: The Science of Scarcity and Diversity, pp 153-181. Sinauer Associates, Sunderland, MA.

[20] Walujo, E. Baroto. 2002. Gatra Etnobotani Eboni (Diospyros celebica BAKH). Berita Biologi. Vol.6. no.2. 